\title{
Attenuation of low-temperature stress in rice seedlings ${ }^{1}$
}

\author{
Mara Grohs², Enio Marchesan², Rodrigo Roso², Bibiana Silveira Moraes ${ }^{2}$
}

\section{ABSTRACT}

Rice is a cold-sensitive crop, and its exposure to lowtemperature stress, during germination and early seedling growth, can negatively affect the initial stand establishment. Substances that act as growth regulators can be used to mitigate this initial stress. Thus, the influence of gibberellic acid, thiamethoxam and a phytohormone was investigated at the growth variables and antioxidant enzyme activity of the 'Irga 424' and 'Puita Inta CL' rice cultivars, at low-temperature $\left(17^{\circ} \mathrm{C}\right)$. The products act on the germination percentage of 'Puita Inta CL', but vigor is only influenced by giberellic acid. Giberellic acid influences shoot length, irrespective of cultivar, while thiamethoxam and the phytohormone only affect length in 'Puita Inta CL'. The antioxidant activity depends on the cultivar and organ tested (shoot or root). These products mitigate the effects of cold, thereby preventing the formation of reactive-oxygen species and lipid peroxidation, and positively influence the superoxide dismutase enzyme activity.

KEY-WORDS: Oryza sativa L.; growth regulator; gibberellic acid.

\section{INTRODUCTION}

Abiotic stress is the primary cause of crop failure worldwide, reducing average yields for most major crops by more than $50 \%$. In response to these stress factors, various genes are upregulated, what can mitigate the stress effect and lead to adjustments in the cellular milieu and plant tolerance (Mahajan \& Tuteja 2005, Gill \& Tuteja 2010).

An important mechanism by which plants are damaged under adverse environmental conditions is the excessive production of reactive oxygen species (ROS), such as superoxide $\left(\mathrm{O}_{2}^{-}\right)$, hydrogen peroxide $\left(\mathrm{H}_{2} \mathrm{O}_{2}\right)$ and hydroxyl radicals $\left(\mathrm{OH}^{-}\right)($Apel \& Hirt 2004).

\section{RESUMO}

Atenuação de estresse

por baixa temperatura em plântulas de arroz

O arrozé uma cultura sensível ao frio, e a exposição ao estresse por baixa temperatura, durante a germinação e crescimento inicial das plântulas, pode afetar negativamente o estabelecimento do estande inicial. Substâncias que agem como reguladores de crescimento podem ser usadas para atenuar esse estresse. Nesse sentido, foi investigada a influência do ácido giberélico, tiametoxam e um fito-hormônio, nas variáveis de crescimento e atividade antioxidante de cultivares de arroz 'Irga 424' e 'Puita Inta CL', sob baixa temperatura $\left(17^{\circ} \mathrm{C}\right)$. Os produtos atuam na porcentagem de germinação de 'Puita Inta CL', mas o vigor somente é influenciado pelo ácido giberélico. O ácido giberélico influencia no comprimento da parte aérea, independentemente da cultivar, enquanto o tiametoxam e o fito-hormônio somente afetam o comprimento em 'Puita Inta CL'. A atividade antioxidante depende da cultivar e do órgão testado (raiz ou parte aérea). Esses produtos mitigam o efeito do frio, por meio da prevenção da formação de espécies reativas ao oxigênio e peroxidação lipídica, e influenciam positivamente na atividade da enzima superóxido dismutase.

PALAVRAS-CHAVE: Oryza sativa L.; regulador de crescimento; ácido giberélico.

Oxidative stress has been shown to occur in plants exposed to higher and lower temperatures, particularly in combination with high light intensities and drought. A common feature among the different ROS types is their capacity to cause oxidative damage to proteins, DNA and lipids (Gill \& Tuteja 2010).

Each plant has its unique set of temperature requirements, which must be optimum for proper growth and development. In rice, the critical minimum temperature for shoot elongation ranges from $7{ }^{\circ} \mathrm{C}$ to $16{ }^{\circ} \mathrm{C}$, and for root elongation from $12{ }^{\circ} \mathrm{C}$ to $16^{\circ} \mathrm{C}$ (Yoshida 1981). In Brazil, rice should be sowed when soil temperature is $17^{\circ} \mathrm{C}$ (Sosbai 2014), from September 1 (to coincide with the maximum solar radiation at flowering). In this

1. Manuscript received in Mar./2016 and accepted for publication in Jun./2016 (http://dx.doi.org/10.1590/1983-40632016v4640436).

2. Universidade Federal de Santa Maria, Departamento de Agronomia, Santa Maria, RS, Brazil.

E-mails: grohs.mara@gmail.com, eniomarchesan@gmail.com,rodrigoroso@yahoo.com.br, bibianamoraes@gmail.com. 
period, soil temperature is low and can cause a delay in germination and emergence up to 32 days between sowing and emergence, when compared to 8 days, in periods of favorable temperatures (Mariot et al. 2009).

The major harmful effect of freezing is severe membrane damage (Morsy et al. 2005). This is largely due to the acute dehydration caused by freezing. Cold sensitive plants usually have a higher proportion of saturated fatty acids and, therefore, a higher transition temperature (Mahajan \& Tuteja 2005).

In plants, ROS are continuously produced as byproducts of various metabolic pathways located in different cellular compartments. Under physiological steady state conditions, these molecules are scavenged by different antioxidative defense components that are often confined to particular compartments. The balance between ROS generation and scavenging may be disturbed by a number of adverse environmental factors, causing a rapid increase in the intracellular levels of ROS (Gill \& Tuteja 2010).

Since rice is a cold-sensitive crop, the exposure to low-temperature stress, during germination and early seedling growth, can severely affect the stand establishment (Yoshida 1981). Thus, mechanisms that improve low-temperature stress tolerance, during germination and early seedling growth, are of immense interest to rice producers, mainly in the Rio Grande do Sul State, responsible for $70 \%$ of the rice produced in Brazil. In this region, low temperature is very common during the growth season of flooded rice (Sosbai 2014).

The use of substances that act as growth regulators may improve seed germination and shoot emergence, particularly in weak or damaged seeds and under adverse conditions, such as temperature extremes or drought, resulting in a stand that is more uniform, vigorous and productive, thereby acting on germination (Cataneo et al. 2010). For example, gibberellic acid ( $\left.\mathrm{GA}_{3}\right)$ can act as a buffer to maintain good germination along with healthy stand establishment for rice (Lee et al. 2012).

Thiamethoxam is a novel broad-spectrum neonicotinoid insecticide used to control Oryzophagus oryzae in flooded rice. Although many reports describe its insecticidal, plant-protecting properties, just a few investigate its effect on seed germination activities, what may be a key control point in seedling vigor. Its mechanism of action is poorly understood in plants and its stimulus on enzyme activity in the antioxidant system has been documented (Cataneo et al. 2010). Other products for treating seeds with an organic composition (polysaccharides, glycoproteins, peptides, fatty acids, amino acids and others), essential to plant growth and development, may have the potential to increase seed vigor by changing nitrogen metabolism.

This study aimed to investigate the effect of cold on germination and antioxidant enzyme activity in two rice cultivars treated with growth-regulating substances.

\section{MATERIAL AND METHODS}

The study was carried out in Santa Maria, Rio Grande do Sul State, Brazil, in 2012, using a Biochemical Oxygen Demand (BOD) incubation chamber equipped with a microprocessor based digital timer of the thermoperiod and photoperiod, forced air circulation in the vertical direction and temperature accuracy of $\pm 0.3{ }^{\circ} \mathrm{C}$.

The experiment was conducted in a two-factor scheme, with four repetitions $(2 \times 4)$. The first factor was composed of seeds from two rice cultivars ('Irga 424' and 'Puita Inta CL'), while the second factor consisted of treating the seeds with gibberellic acid, thiamethoxam and a phytohormone (Haf Plus ${ }^{\mathbb{R}}$ ) [mixture of nitrogen $(5 \%)+$ organic matter $(25 \%)$, L- $\alpha$ amino acids (6\%), Ascophyllum nodosum seaweed extract, polysaccharides, micronutrients $(0.72 \%)]$, and a control with water. The experiment was conducted at a temperature of $17^{\circ} \mathrm{C}$.

The products were applied directly to the seeds with a pressurized valve, $24 \mathrm{~h}$ before sowing. Fifteen grams of seeds from each cultivar were weighed, then treated with $0.7 \mathrm{~mL}$ of water and two drops of methylene blue designed to better visualize spray uniformity. Treatment flow was $4.6 \mathrm{~L} 100 \mathrm{~kg}^{-1}$ of seeds.

Plant growth was quantified by germination percentage measurement of shoot and root lengths. For germination, four replicates of 100 seeds from each treatment were distributed on two sheets of blotter paper moistened with water (equivalent to 2.5 times the paper weight). Seedlings were evaluated at 7 and 14 days after sowing (DAS) (Brasil 2009). Results were expressed as the mean percentage of normal seedlings.

To measure shoot and root length, four replicates of 10 seeds were sown on a line drawn 
on the upper third of the paper. Seedling length was measured with a millimeter ruler at 10 and 14 DAS. The values were obtained by adding the measurements of each repetition and dividing them by the number of seedlings. Seedlings from the germination test were separated into roots and shoots and frozen to carry out the biochemical tests.

The hydrogen peroxide content in the shoot and roots of seedlings treated with the products and the control treatment was determined according to Loreto \& Velikova (2001). Lipid peroxidation was followed by the measurement of malondialdehyde (MDA) accumulation according to El-Moshaty et al. (1993). The activity of the superoxide dismutase (SOD), catalase (CAT) and ascorbate peroxidase (APX) enzymes was assayed according to McCord \& Fridovich (1969), Aebi (1984) and the modified method of Zhu et al. (2004), respectively. In all the enzyme preparations, protein was measured by the Coomassie Blue method (Bradford 1976), using BSA as a standard.

Statistical analysis was performed applying the Scott-Knott test at $5 \%$. Germination percentage (7 and 14 DAS) was transformed by the equation $\mathrm{yt}=\sqrt{\mathrm{y}}+1$.

\section{RESULTS AND DISCUSSION}

The interaction between cultivars and products used was observed for all the variables analyzed (Table 1). In the germination stage, chilling injury symptoms are the most commonly observed in the delay and decrease in germination percentage (Mertz et al. 2009). Temperature has a significant influence on germination by affecting the activation stage and post germination growth. The effects of temperature on germination can be examined in relation to three aspects: temperature, time and germination percentage. In the present study, when rice seeds were treated with growth regulators, there was an increase in germination percentage, when compared to the control treatment (distilled water), in the 'Puita Inta CL' cultivar (Figure 1A).

For the 'Puita Inta CL' cultivar, $\mathrm{GA}_{3}$ changed the germination rate $(23 \%$ of seedlings in the first evaluation), at $7 \mathrm{DAS}$, while the other treatments showed no seed germination. However, from 14 DAS, all the products were effective in stimulating germination, with a difference of $20 \%$, if compared to the control treatment. For the 'Irga 424' cultivar, no significant difference was observed between treatments.

The shoot and root lengths were quantified to identify the organ of action of products (Figures 1B and $\mathrm{C}$ ). For $\mathrm{GA}_{3}$, there is a preference for shoot growth over the root system, in both cultivars. This is because $\mathrm{GA}_{3}$ acts on mesocotyl elongation, mainly in Indica subspecies cultivars, showing a $10 \mathrm{~mm}$ difference between seedlings treated with $\mathrm{GA}_{3}$ and control seedlings, due to increased cell wall plasticity and sugar hydrolysis, reducing water potential in the cell, resulting in water ingress and seedling elongation, especially in the mesocotyl (Lee et al. 2012). For thiamethoxam, there was a predominant growth of the root system up to 14 DAS, for 'Puita Inta CL'. The effect of thiamethoxam on the root system of plants has been reported by several authors

Table 1. Results of analysis of variance (Anova) of the Oryza sativa L. cultivar, products and their interaction for germination, shoot length, root length, $\mathrm{H}_{2} \mathrm{O}_{2}$ content, lipid peroxidation (MDA), ascorbate oxidase (APX), catalase (CAT) and superoxide dismutase (SOD) activities.

\begin{tabular}{|c|c|c|c|c|c|}
\hline \multirow{2}{*}{$\begin{array}{l}\text { Dependent } \\
\text { variable }\end{array}$} & \multirow{2}{*}{ Organ } & \multirow{2}{*}{ Day } & \multicolumn{3}{|c|}{ Independent variable } \\
\hline & & & Cultivar (C) & Product $(\mathrm{P})$ & $\mathrm{C} \times \mathrm{P}$ \\
\hline \multirow{2}{*}{ Germination } & - & 7 & $0.52 *$ & $2.20 *$ & $0.40^{*}$ \\
\hline & - & 14 & $0.09 *$ & $0.11 *$ & $0.03 *$ \\
\hline \multirow{4}{*}{ Length } & \multirow{2}{*}{ Shoot } & 10 & $0.88 *$ & $1.34 *$ & $0.10^{*}$ \\
\hline & & 14 & $15.69 *$ & $22.88 *$ & $1.56^{*}$ \\
\hline & \multirow{2}{*}{ Root } & 10 & $11.25^{*}$ & $0.99 *$ & $0.36^{*}$ \\
\hline & & 14 & $31.3 *$ & $1.00 *$ & $2.06^{*}$ \\
\hline \multirow{4}{*}{$\mathrm{H}_{2} \mathrm{O}_{2}$ content } & \multirow{2}{*}{ Shoot } & 7 & $0.0002 *$ & $0.002 *$ & $0.001 *$ \\
\hline & & 14 & $0.0004 *$ & $0.002 *$ & $0.001 *$ \\
\hline & \multirow{2}{*}{ Root } & 7 & $0.0001 *$ & $0.00007^{*}$ & $0.00009 *$ \\
\hline & & 14 & $0.0005 *$ & $0.00004^{\mathrm{ns}}$ & $0.0001 *$ \\
\hline \multirow{4}{*}{ MDA content } & \multirow{2}{*}{ Shoot } & 7 & $1.19 *$ & $0.27 *$ & $0.24^{*}$ \\
\hline & & 14 & $3.52 *$ & $2.63 *$ & $2.89 *$ \\
\hline & \multirow{2}{*}{ Root } & 7 & $1.99 *$ & $12.37^{*}$ & $3.03 *$ \\
\hline & & 14 & $0.38^{*}$ & $2.49 *$ & $0.32 *$ \\
\hline \multirow{4}{*}{ APX activity } & \multirow{2}{*}{ Shoot } & 7 & $0.18^{*}$ & $0.26^{*}$ & $0.059 *$ \\
\hline & & 14 & $0.21 *$ & $0.19 *$ & $0.02 *$ \\
\hline & \multirow{2}{*}{ Root } & 7 & $0.02 *$ & $0.57^{*}$ & $0.03 *$ \\
\hline & & 14 & $0.15^{*}$ & $0.15^{*}$ & $0.49 *$ \\
\hline \multirow{4}{*}{ CAT activity } & \multirow{2}{*}{ Shoot } & 7 & $1.77^{*}$ & $4.05 *$ & $3.6^{*}$ \\
\hline & & 14 & $0.8^{*}$ & $4.78 *$ & $0.92 *$ \\
\hline & \multirow{2}{*}{ Root } & 7 & $3.65^{*}$ & $3.44 *$ & $1.17^{*}$ \\
\hline & & 14 & $1.57 *$ & $3.97 *$ & $4.76^{*}$ \\
\hline \multirow{4}{*}{ SOD activity } & \multirow{2}{*}{ Shoot } & 7 & $0.0006^{\mathrm{ns}}$ & $0.012^{*}$ & $0.013^{*}$ \\
\hline & & 14 & $0.31 *$ & $0.001 *$ & $0.08 *$ \\
\hline & \multirow{2}{*}{ Root } & 7 & $4.13^{*}$ & $2.29 *$ & $1.91 *$ \\
\hline & & 14 & $0.03 *$ & $0.04 *$ & $0.012 *$ \\
\hline
\end{tabular}

Numbers represent $\mathrm{F}$ values at $5 \%$ : ${ }^{\mathrm{ns}}$ not significant; ${ }^{*}$ significant for $\mathrm{p} \leq 0.05$. 
(Tavares et al. 2007, Lauxen et al. 2010, Almeida et al. 2011), but the reasons that lead to this stimulus have yet to be elucidated. In the field, this effect was attributed to greater water and nutrient absorption (Tavares et al. 2007). There were no significant differences in 'Irga 424', while, for 'Puita Inta CL', the effect of thiamethoxam on the root system was accompanied by phytohormone.

Disturbances to the germination process under stress conditions lead to excessive production of reactive oxygen species (ROS), in the absence of effective protection mechanisms (enzymatic or not), and metabolic changes that result in oxidative damage (Pan et al. 2006). In the present study, the control treatment showed the highest $\mathrm{H}_{2} \mathrm{O}_{2}$ increase in the shoots under chilling stress, if compared to treatments with growth regulators, 7 and 14 DAS (Figure 2A), indicating that products mitigate abiotic stress (in this case the cold), avoiding the formation of ROS and their harmful effects on cell constituents.

However, this effect was only observed in the seedling shoots, because the $\mathrm{H}_{2} \mathrm{O}_{2}$ production in the root varied considerably between treatments (Figure 2B). At 7 and 14 DAS, significant differences were found only in the 'Puita Inta CL' cultivar, with an increase in $\mathrm{H}_{2} \mathrm{O}_{2}$ production in the roots of plants treated with $\mathrm{GA}_{3}$. Gibberellins are effective in stimulating mesocotyl elongation, promoting a
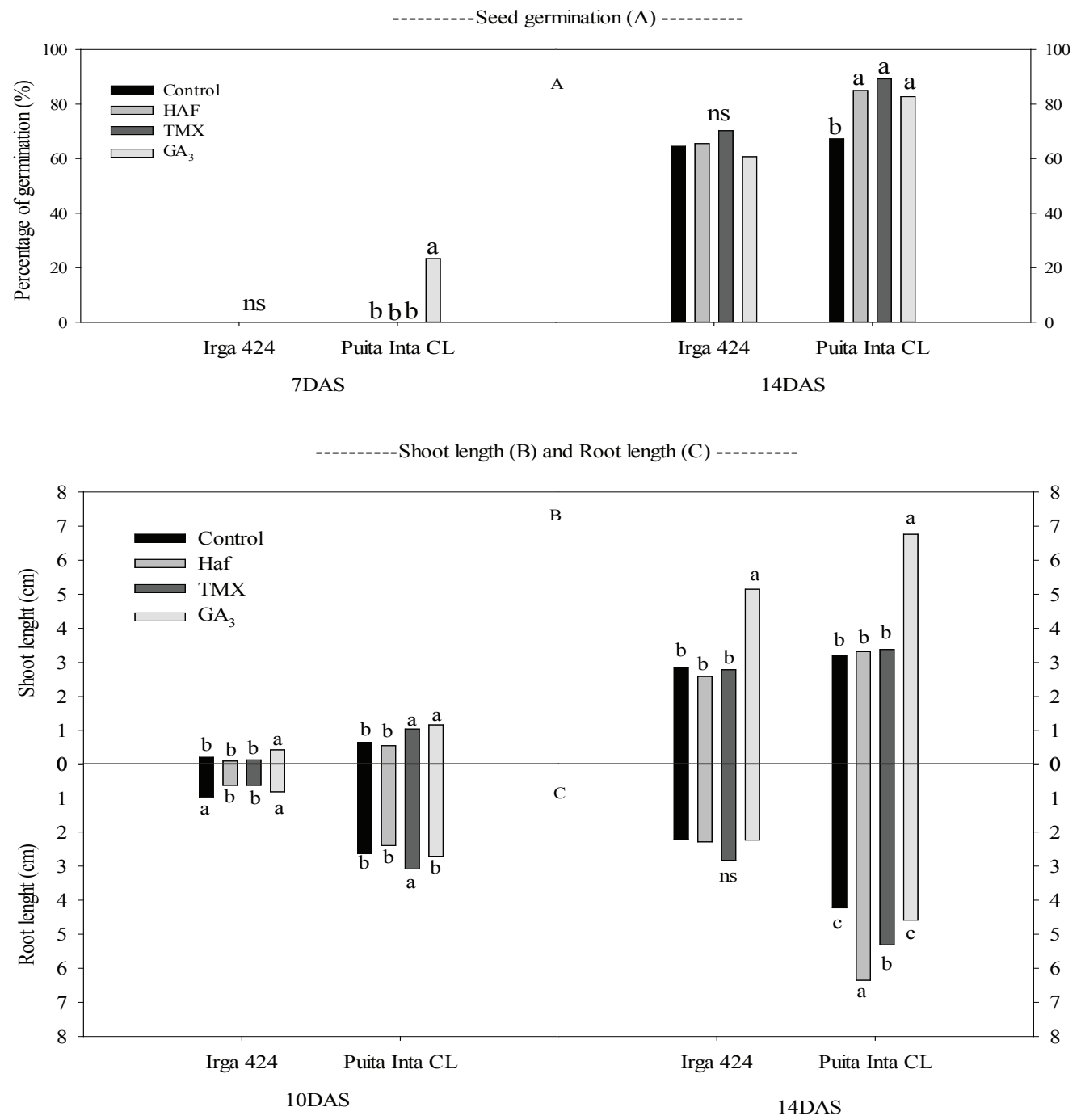

Figure 1. Effect of products, control, phytohormone (Haf), thiamethoxam (TMX) and gibberellic acid (GA $)_{3}$ on germination percentage (A), shoot length (B) and root length (C) (cm) of two rice cultivars ('Irga 424' and 'Puita Inta CL'), at low temperature $\left(17^{\circ} \mathrm{C} ; 10\right.$ and 14 days after sowing - DAS). Different letters indicate significantly different means between treatments $(\mathrm{p} \leq 0.05)$. 
rapid development of the seedling shoot (Yamaguchi 2008, Dai \& Xue 2010). However, when shoot growth becomes excessive, the seedling moves its metabolites to nourish the organ at the expense of root development. This can lead to inhibited root growth. This inhibition is apparently responsible for the increase in $\mathrm{H}_{2} \mathrm{O}_{2}$ in the root.

ROS resulting from severe stress may cause lipid peroxidation damage to cell membranes, protein degradation of double-stranded breaks in DNA and cell death (Apel \& Hirt 2004). Lipid peroxidation is the result of the presence of $\mathrm{H}_{2} \mathrm{O}_{2}$ caused by oxidative damage and its intensity may vary depending on the velocity of oxidative protection (Munns \& Tester 2008). In this study, the high concentration of $\mathrm{H}_{2} \mathrm{O}_{2}$ in the control treatment affected the lipid peroxidation of the shoots at 7 and 14 DAS, in both cultivars used (Figure 3A). For the root, however, thiamethoxam and the phytohormone had a negative effect, showing high lipid peroxidation in both cultivars, at 7 and 14 DAS (Figure 3B). Although it had a positive influence on the germination of rice seedlings, depending on the dose used, thiamethoxam may exhibit toxicity symptoms (Almeida et al. 2011). Moreover, according to Cavusoglu et al. (2011), increasing thiamethoxam doses can cause changes in mitosis and chromosomal aberrations, reducing the mitotic index and increasing lipid peroxidation, resulting in a decrease in the Allium cepa L. germination.

To mitigate the high production of ROS, plants have developed a good antioxidant defense system at the cellular level. The extent of oxidative stress in a cell is determined by the amount of superoxide, $\mathrm{H}_{2} \mathrm{O}_{2}$ and hydroxyl radicals. Therefore, the balance of superoxide dismutase (SOD), ascorbate peroxidase (APX) and catalase (CAT) activities is crucial for suppressing toxic ROS levels in a cell.

Figures 4, 5 and 6 illustrate the activity of the antioxidant defense system represented by APX, CAT and SOD. APX activity showed an increase for most treatments, especially for the control treatment (Figures 4A and 4B). Stressed plants commonly react this way because the larger amount of $\mathrm{H}_{2} \mathrm{O}_{2}$ produced in this treatment acts as a second messenger inside the cell (Forman et al. 2010). This leads to the increased production of antioxidant enzymes (APX,

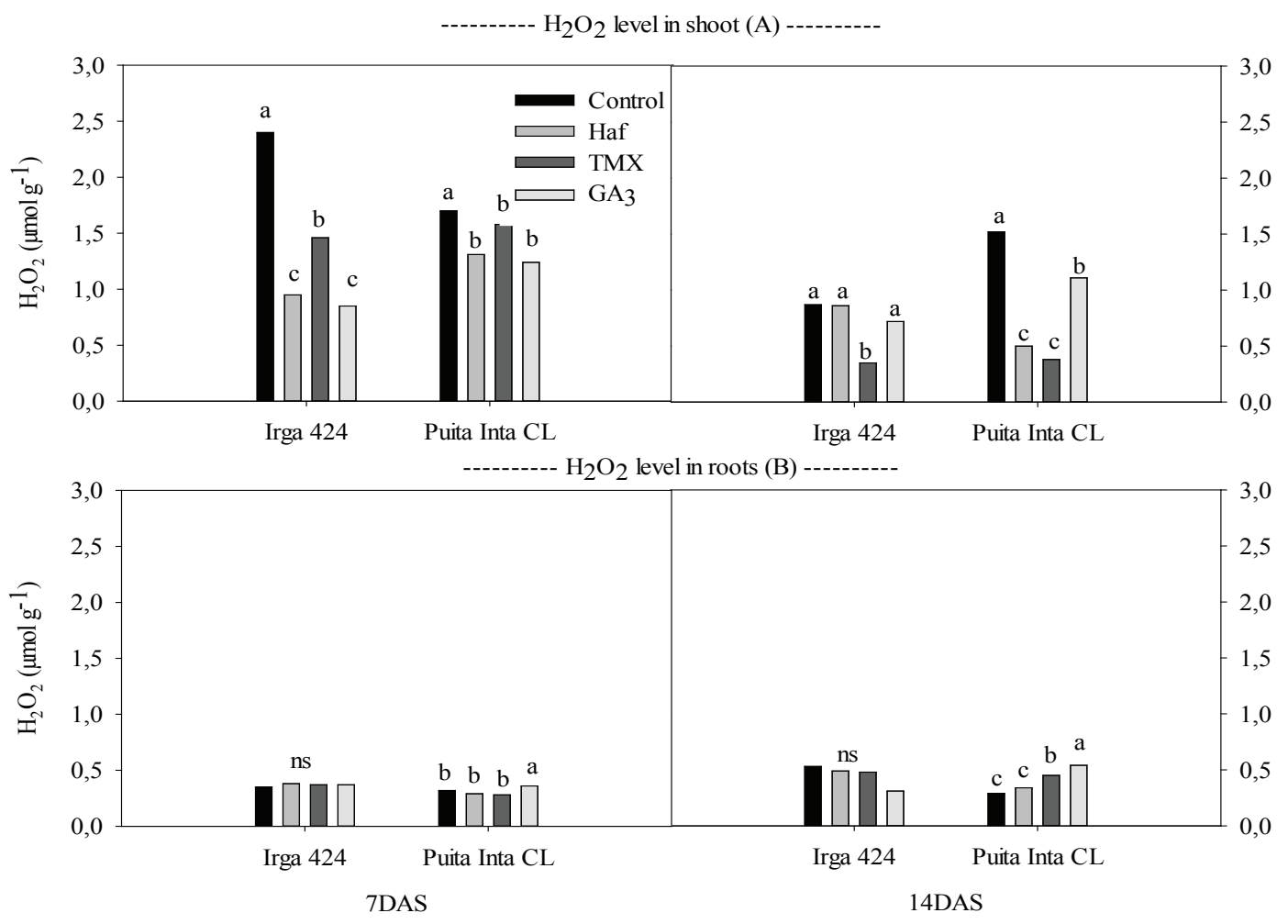

Figure 2. Endogenous content of oxidative products $\left(\mathrm{H}_{2} \mathrm{O}_{2}\right)$ in rice seedlings, as a result of exposure to different products, under stress conditions [control, phytohormone (Haf), thiamethoxam (TMX) and gibberellic acid $\left(\mathrm{GA}_{3}\right)$ ]. Different letters indicate a significantly different mean between treatments $(\mathrm{p} \leq 0.05)$. 

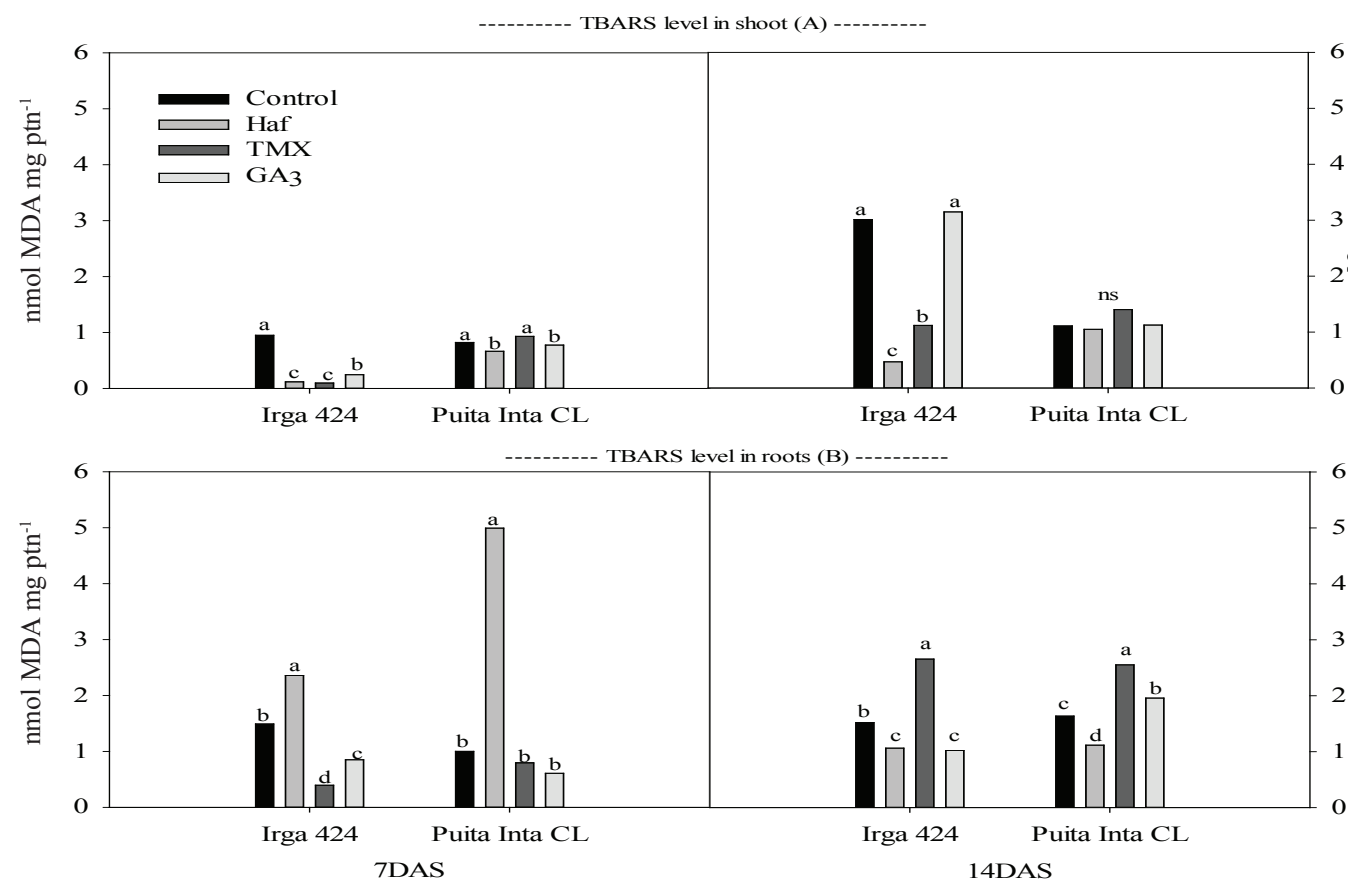

Figure 3. Lipid peroxidation in the rice seedlings, as a result of exposure to different products, under stress conditions [control, phytohormone (Haf), thiamethoxam (TMX) and gibberellic acid $\left(\mathrm{GA}_{3}\right)$ ]. Different letters indicate a significantly different mean between treatments $(\mathrm{p} \leq 0.05)$.
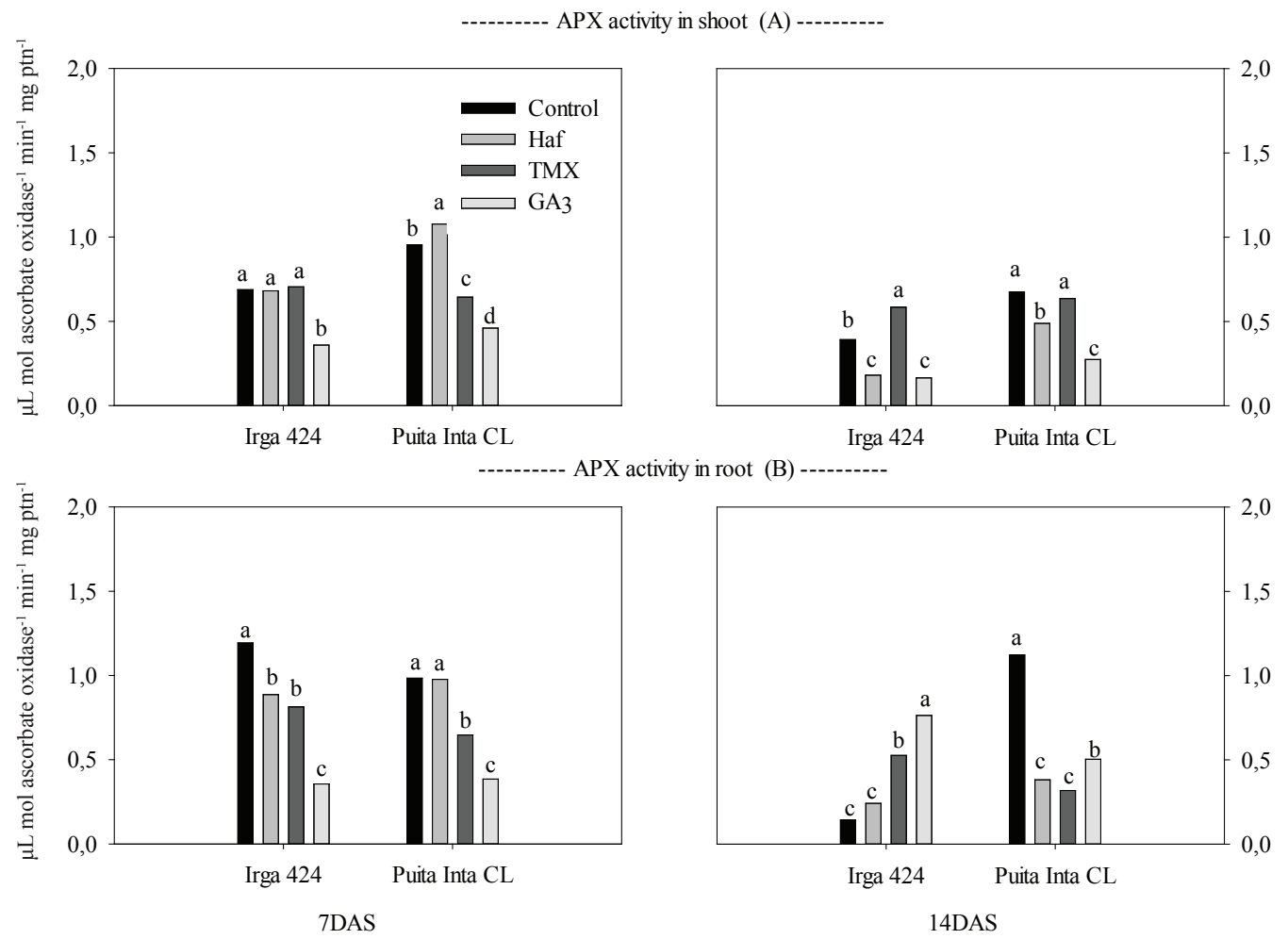

Figure 4. Ascorbate oxidase (APX) activity in the shoots (A) and roots (B) of 'Irga 424' and 'Puita Inta CL' cultivars, before treatment with products, under stress conditions [control, phytohormone (Haf), thiamethoxam (TMX) and gibberellic acid $\left(\mathrm{GA}_{3}\right)$ ], at low temperature $\left(17{ }^{\circ} \mathrm{C} ; 7\right.$ and 14 days after sowing - DAS). Different letters indicate a significantly different mean between treatments $(\mathrm{p} \leq 0.05)$. 
in this case), in an attempt to detoxify the cell. The treatment with $\mathrm{GA}_{3}$ showed the lower activity of this enzyme in the shoots, probably because this growth regulator minimizes cold-related stress by activating hydrolytic enzymes such as $\alpha$-amylase, which stimulates germination and shoot growth, even under stress conditions. The highest APX activity in the root was also dominant in the control treatment.

In contrast to APX, products showed greater CAT enzyme activity in the shoot and root of the 'Irga 424' cultivar (Figures 5A and 5B). For 'Puita Inta CL', the highest CAT activity was quantified in the control treatment. There is a difference in cold sensitivity between rice cultivars. According to Cruz et al. (2010), Indica subspecies cultivars are less tolerant to this type of abiotic stress. 'Irga 424' is classified as cold sensitive, with low initial vigor (Cruz et al. 2010), while 'Puita Inta CL' is classified as having high initial vigor and moderate tolerance to cold. These genetic traits led to the result obtained in the present study. With respect to their high sensitivity to cold, 'Irga 424' did not respond to the treatment with growth regulators, in contrast to 'Puita Inta CL', concerning germination. There was an increase in $\mathrm{H}_{2} \mathrm{O}_{2}$ production and consequently greater stimulus to enzyme activation for the detoxification that occurred in all treatments. It was demonstrated that 'Puita Inta $\mathrm{CL}^{\prime}$ ' is more responsive to growth regulators, what had a positive influence on germination. The consequences of stress were minimized, but not in the control treatment, resulting in an increased presence of ROS, and a consequent rise in enzyme activity antioxidants, such as CAT, in the shoot and root. There was a significant stimulus of $\mathrm{GA}_{3}$ in the root of 'Irga 424', at 14 DAS.

Among the enzymes, SOD activity showed the lowest activity, when compared to the other enzymes studied. The activity of this enzyme depends on the cultivar and organ evaluated. SOD activity in the shoot of the 'Irga 424' cultivar (Figure 6) was stimulated mainly in seedlings treated with phytohormone, while, in 'Puita Inta CL', there was greater activity for $\mathrm{GA}_{3}$ and thiamethoxam, depending on the evaluation.
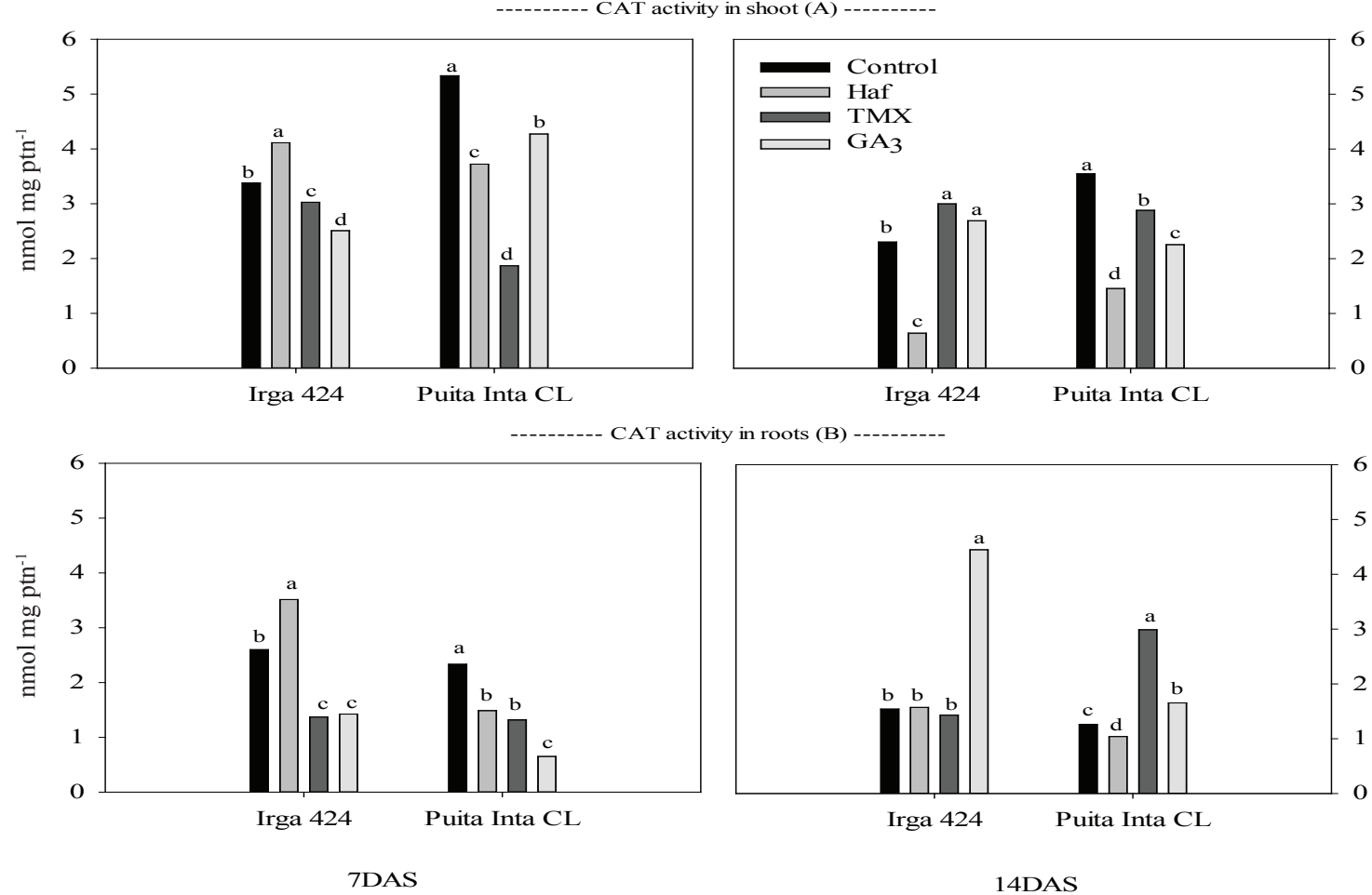

Figure 5. Catalase (CAT) activity in the shoots (A) and roots (B) of 'Irga 424' and 'Puita Inta CL' cultivars, before treatment with the products at low temperature $\left(17^{\circ} \mathrm{C} ; 7\right.$ and 14 days after sowing - DAS), under stress conditions [control, phytohormone (Haf), thiamethoxam (TMX) and gibberellic acid $\left.\left(\mathrm{GA}_{3}\right)\right]$. Different letters indicate a significantly different mean between treatments $(\mathrm{p} \leq 0.05)$. 


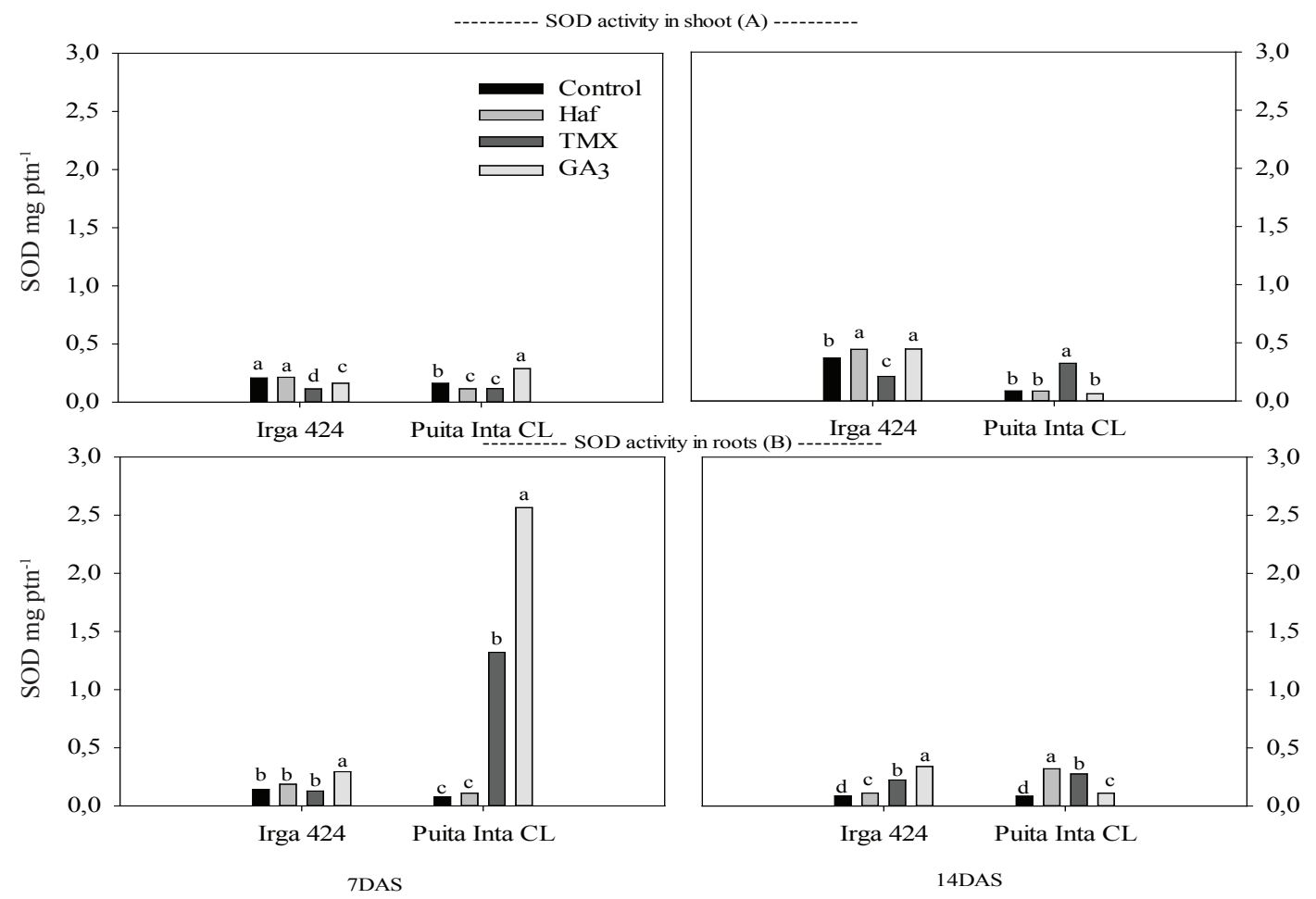

Figure 6. Superoxide dismutase (SOD) activity in the shoots (A) and roots (B) of 'Irga 424' and 'Puita Inta CL' cultivars, before treatment with the products at low temperature $\left(17^{\circ} \mathrm{C} ; 7\right.$ and 14 days after sowing - DAS), under stress conditions [control, phytohormone (Haf), thiamethoxam (TMX) and gibberellic acid $\left.\left(\mathrm{GA}_{3}\right)\right]$. Different letters indicate a significantly different mean between treatments $(\mathrm{p} \leq 0.05)$.

There was an increase in the $\mathrm{GA}_{3}$ activity in the root of 'Irga 424' (Figure 6B), while, for 'Puita Inta CL', all the products were effective at increasing SOD activity, with lower activity for the control treatment. This result is extremely important, because SOD is an enzyme in the first line of the plant defense, transforming the superoxide into $\mathrm{H}_{2} \mathrm{O}_{2}$, while APX and CAT detoxify $\mathrm{H}_{2} \mathrm{O}_{2}$. Thus, the $\mathrm{H}_{2} \mathrm{O}_{2}$ formed in response to temperature stress is rapidly converted into -OH, which is a less toxic product of ROS. Moreover, the lower presence of $\mathrm{H}_{2} \mathrm{O}_{2}$ in the treatments with the products demonstrated that they act predominantly on the activity of the SOD enzyme, decreasing $\mathrm{H}_{2} \mathrm{O}_{2}$ production and likely reducing the participation of CAT and APX enzymes.

\section{CONCLUSIONS}

1. Gibberellic acid, thiamethoxam and the phytohormone increase the final germination only in the 'Puita Inta CL' cold-tolerant cultivar.

2. Vigor is only influenced by gibberellic acid in 'Puita Inta CL'.
3. Gibberellic acid influences the shoot growth of seedlings, while the phytohormone and thiamethoxam affect the root system.

4. These products mitigate the effects of cold, thereby preventing the formation of $\operatorname{ROS}\left(\mathrm{H}_{2} \mathrm{O}_{2}\right)$ and lipid peroxidation in the shoot, and positively influencing SOD and CAT enzyme activity. This is primarily the case for 'Irga 424', which shows less activity in the root system of rice seedlings.

\section{REFERENCES}

AEBI, H. Catalase in vitro. Methods in Enzymology, v. 105, n. 2, p. 121-126, 1984.

ALMEIDA, A. S. et al. Bioativador no desempenho fisiológico de sementes de arroz. Revista Brasileira de Sementes, v. 33, n. 3, p. 501-510, 2011.

APEL, K.; HIRT, H. Reactive oxygen species: metabolism, oxidative stress, and signal transduction. Annual Review of Plant Biology, v. 55, n. 1, p. 373-99, 2004.

BRADFORD, M. M. A. A rapid and sensitive method for the quantification of microgram quantities of protein 
utilizing the principle of protein dye binding. Analytical Biochemistry, v. 72, n. 1-2, p. 248-254, 1976.

BRASIL. Ministério da Agricultura, Pecuária e Abastecimento. Regras para análise de sementes. Brasília: DF: Ministério da Agricultura, 2009.

CATANEO, A. C. et al. Improved germination of soybean seed treated with thiamethoxam under drought conditions. Seed Science and Technology, v. 38, n. 1, p. 248-251, 2010.

CAVUSOGLU, K. Physiological, anatomical, biochemical, and cytogenetic effects of thiamethoxam treatment on Allium cepa (Amaryllidaceae) L. Environmental Toxicology, v. 27, n. 11, p. 635-543, 2011.

CRUZ, R. P. da; DUARTE, I. T. L.; CABREIRA, C. Inheritance of rice cold tolerance at the seedling stage. Science Agricola, v. 67, n. 6, p. 669-674, 2010.

DAI, C.; XUE, H. Rice early flowering1, a CKI, phosphorylates DELLA protein SLR1 to negatively regulate gibberellin signaling. The EMBO Journal, v. 29, n. 11, p. 1916-1927, 2010.

EL-MOSHATY, F. I. B. et al. Lipid peroxidation and superoxide production in cowpea (Vigna unguiculata) leaves infected with tobacco ringspot virus or southern bean mosaic virus. Physiological and Molecular Plant Pathology, v. 43, n. 1, p. 109-119, 1993.

FORMAN, H. J.; MAIORINO, M.; URSINI, F. Signaling functions of reactive oxygen species. Biochemistry, v. 49, n. 5, p. 835-842, 2010.

GILL, S. S.; TUTEJA, N. Reactive oxygen species and antioxidant machinery in abiotic stress tolerance in crop plants. Plant Physiology and Biochemistry, v. 48, n. 12, p. 909-930, 2010.

LAUXEN, L. R.; VILLELA, F. A.; SOARES, R. C. Desempenho fisiológico de sementes de algodoeiro tratadas com tiametoxam. Revista Brasileira de Sementes, v. 32, n. 3, p. 61-68, 2010.

LEE, H. et al. Mapping and characterization of quantitative trait loci for mesocotyl elongation in rice (Oryza sativa L.). Rice, v. 5, n. 13, p. 1-10, 2012.

LORETO, F.; VELIKOVA, V. Isoprene produced by leaves protects the photosynthetic apparatus against ozone damage, quences ozone products, and reduces lipid peroxidation of cellular membranes. Plant Physiology, v. 127, n. 4, p. 1781-1787, 2001.

MAHAJAN, S.; TUTEJA, N. Cold, salinity and drought stresses: an overview. Biochemistry and Biophysics, v. 444, n. 2, p. 139-158, 2005.
MARIOT, C. H. P. et al. Ensaio bioclimático de arroz irrigado nas regiões da Planície Costeira Externa e Fronteira Oeste do RS: safra 2008/09. In: CONGRESSO BRASILEIRO DE ARROZ IRRIGADO, 6., 2009, Porto Alegre. Anais... Porto Alegre: Sosbai, 2009. 1 CD-ROM.

McCORD, J. M.; FRIDOVICH, I. Superoxide dismutase: an enzymic function for erythrocuprein (hemocuprein). Journal of Biological Chemistry, v. 244, n. 22, p. 60496055, 1969.

MERTZ, L. M. et al. Alterações fisiológicas em sementes de arroz expostas ao frio na fase de germinação. Revista Brasileira de Sementes, Londrina, v. 31, n. 2, p. 254-262, 2009.

MORSY, M. R. et al. The OsLti6 genes encoding low molecular weight membrane proteins are differentially expressed in rice cultivars with contrasting sensitivity to low temperature. Gene, v. 80 , n. 1, p. 344-171, 2005.

MUNNS, R.; TESTER, M. Mechanisms of salinity tolerance. Annual Review of Plant Biology, v. 59, n. 3, p. 651-81, 2008.

PAN, Y.; WU, L. J.;YU, Z. L. Effect of salt and drought stress on antioxidant enzymes activities and SOD isoenzymes of liquorice (Glycyrrhiza uralensis Fisch). Plant Growth Regulation, v. 49, n. 3, p. $157-$ 165, 2006.

SOCIEDADE SUL-BRASILEIRA DE ARROZ IRRIGADO (Sosbai). Arroz irrigado: recomendações técnicas da pesquisa para o Sul do Brasil. In: REUNIÃO TÉCNICA DA CULTURA DO ARROZ IRRIGADO, 30., 2004, Bento Gonçalves. Anais... Porto Alegre: Sosbai, 2014. p. 1-192.

TAVARES, S. et al. Avaliação dos efeitos fisiológicos de tiametoxam no tratamento de sementes de soja. Revista de Agricultura, v. 82, n. 1, p. 47-54, 2007.

YAMAGUCHI, S. Gibberellin metabolism and its regulation. Annual Review of Plant Biology, v. 59, n. 1, p. 225-251, 2008.

YOSHIDA, S. Fundamentals of rice crop science. Los Baños: International Rice Research Institute, 1981.

ZHU, Z. et al. Silicon alleviates salt stress and increases antioxidant enzymes activity in leaves of salt-stressed cucumber (Cucumis sativus, I.). Plant Science, v. 167, n. 2, p. 527-533, 2004. 